\title{
Future Anticipation in Sociology
}

\author{
Carlos Miguel Ferreira, ${ }^{1}$ Sandro Serpa ${ }^{2,3,4,{ }^{*}}$ \\ 1. Interdisciplinary Centre of Social Sciences - CICS.NOVA, Portugal; Estoril Higher Institute for Tourism and Hotel Studies, Portugal \\ 2. University of the Azores, Faculty of Social and Human Sciences, Department of Sociology, Portugal \\ 3. Interdisciplinary Centre of Social Sciences - CICS.UAc/CICS.NOVA.UAc, Portugal \\ 4. Interdisciplinary Centre for Childhood and Adolescence - NICA - UAc, Portugal \\ *: All corresponding should be sent to Dr. Sandro Serpa. \\ Authors' Contact: Carlos Miguel Ferreira, E-mail: carlos.ferreira@eshte.pt; Sandro Serpa, E-mail: sandro.nf.serpa@uac.pt \\ Funding: This work is financed by national funds through FCT - Foundation for Science and Technology, I.P., within the scope of the project \\ «UIDB 04647/2020» of CICS.NOVA-Centro Interdisciplinar de Ciências Sociais da Universidade Nova de Lisboa. \\ DOI: https://doi.org/10.15354/si.21.re229 \\ The authors declare no competing interest
}

The ability to make forecasts about events is a goal favored by the so-called exact sciences. In sociology and other social sciences, the forecast, although often sought after, is not likely to be realized unconditionally. This article seeks to problematize and discuss the connection between sociology and forecast. The object of study of sociology has particular features that distinguish it from other scientific fields, namely facts and social situations, which deal with trends; the systems of belief of social scientists and policymakers that can influence the attempt to anticipate the future; the dissemination of information and knowledge produced by sociology and other social sciences, which have the potential to change reality and, consequently, to call into question their capacity for the social forecast. These principles pose challenges to sociology's heuristic potentials, making the reflection on these challenges indispensable in the scientific approach to social processes.

Keywords: Sociology; Forecasting; Prediction; Foresight; Social Change; Future

Science Insights, 2021 October 11; Vol. 39, No. 1, pp.333-341.

(c) 2021 Insights Publisher. All rights reserved.

(c) (i) (5) Creative Commons Non Commercial CC BY-NC: This article is distributed under the terms of the Creative Commons Attribution-NonCommercial 4.0 License which permits non-commercial use, reprod

Introduction

$\mathrm{T}$ HIS article aims to discuss the potentials and limitations inherent in the possibility of making forecasts in sociology. It is intended to understand whether this science has heuristic potentials, in addition to carrying out analyses on the facts and social situations of the past and present, participating in the construction of knowledge about the future and, in particular, making forecasts about social processes. Ultimately, the purpose of science is the knowledge of processes, which necessarily integrate the dimension of the future (1).

As Comte mentioned, science would aim to provide explanations, forecasts and practical guidelines (2), and science would aim at knowing, to forecast, to prevent, and would seek to investigate the laws that govern natural and social phenomena
(2). Thus, the law would be necessary to forecast, while rational forecast would be necessary to act on nature, providing individuals with dominion over the latter: science, hence prediction; prediction, hence action (2). According to this perspective, society would be governed by social laws that could be identified, and then a policy could be implemented that would allow forecasting the meaning of history, which, to a large extent, would enable the clarification of an overview of the human future.

The belief that social sciences in general, and sociology in particular, would have, as their main purpose, the historical prediction materialized by the discovery of the laws of evolution of history and society would be the central precept of historicism (3). Historical prophecy about a universal history that follows a predetermined path under constant conditions is an impossible 
principle. The "laws of development" (3, p.128) inherent in historicism emphasize absolute tendencies, which, like laws, do not depend on initial conditions and that lead inevitably towards a certain future. They are the pillars of unconditioned prophecies, as opposed to conditional scientific predictions (3). Another relevant aspect is related to the impossibility of universal laws of an evolutionary type because the evolution of societies would be a unique historical case from which no replication can be obtained (3). The main consequence of this position is that only conditional scientific prediction, which would recognize the variability of local circumstances and specific initial conditions, would be valid. The most a scientific theory does is to forecast certain events in the future, based on what it claims about reality. However, science cannot predict what knowledge it will discover in the future (3).

Horkheimer drew a distinction between "forecast" and "prediction". The natural sciences know two types of judgments, forecast - which relates to "abstract models" - and prediction which concerns "concrete acts or facts" (1). A theory that supported the possibility of leading modern science only at the level of forecast but not at the level of predictions understood in this sense, would, indeed, be making a mistake. The natural sciences, like all science in general, favor predictions (1).

"Abstract models", in the sense of forecast, are laws and, as such, have, in substance, constantly a conditional form. They always mean that when certain conditions take place in reality, the determined facts must necessarily occur (1). However, laws are not the objective of scientific activity but only a working instrument. The essential thing is always to move from formulas in the form of abstract laws to existential and concrete judgments. These do not simply imply, for the whole of the domain of the natural sciences, statements about the past or the present, but always, and at the same time, also predictions for the future (1). In the analyses developed by sociology and social sciences, forecast and prediction judgments are necessarily related, in the sense that every hypothetical forecast depends on its historical materialization, also conditioning our perceptions, our judgments, and our practical actions (1). This position refers to the relevance of reflexivity of social sciences, inasmuch that they deal with the relationships between agents that build reality, being influenced by it. Therefore, a theory that intends to account for social phenomena must be concerned with the contextual-historical dimension of the object of analysis.

The social sciences approach the social in a rigorous way, with different perspectives of analysis $(4,5)$. Sociology, like all social sciences, has a historical dimension: "[...] aware that societies are installed in change, of the multiplicity of social times, aware of the irreversibility and uniqueness of facts and the historical thickness of social structures" (5, p.24). In terms of fundamental concerns, sociology and history are analogous, as both seek to understand the challenges of human agency, and both seek this goal in terms of the social structuring process (6).

In sociology, considering the future as contingent and unpredictable, research on the futures focuses on the dynamics of imagination and creation of the future, current trends, possible and probable scenarios, and their social implications (7). This goal can be expressed in the following types of approaches: (i) specific forecasts, such as projections of current demographic trends or the so-called Delphi interviews with experts about their expectations regarding R\&D (research and development); (ii) construction of alternative scenarios or simulations of futures that seem possible or probable; (iii) studies of social imagination and future creation, that is, empirical research on images of the future formulated in the past or present, as well as on the processes by which such visions are constructed and may or may not be effective; and (iv) normative or normative-analytic research on desirable futures, including research on the relationship between values and futures (7). This typology of reflections on the future expresses a polyhedral notion of the studies of the future characterized by interdisciplinarity and theoretical, methodological and technical plurality. However, several assumptions that characterize the studies of the future can be stated: the future cannot be predicted but alternatives for the future can be identified, analyzed and selected; the preferable futures can be enunciated and implemented; the analysis of the activities of the future must precede planning and strategy, supporting strategy-oriented decisions (8).

\section{Methodology}

This article aims to discuss the possibilities, potentials and limitations of making predictions by sociology. Thus, an intensive-qualitative methodology was favored. It is about understanding the multiplicity of features and dimensions that characterize the plural discursive space of sociology about the possibility of analyzing the future.

To attain the purpose underlying this conceptual article, a documentary search was carried out on the RCAAP platform (Open Access Scientific Repositories of Portugal) and on the SCILIT database (www.scilit.net), which indexes scientific material from CrossRef, PubMed, Scopus and Web of Knowledge, between January 25 and 30, 2021. The terms used in the search were "sociology", "forecast" and "social forecast", both in the title and in the abstract of scientific publications.

Documentary analysis was the technique used in this research, developed from different types of documentary sources, such as manuals, academic theses and articles produced in the field of sociology and social sciences, albeit the scientific articles produced on this topic within the scope of sociology and social sciences were favored. The authors deem that the article is the central formal means of the process of scientific production and communication, accounting for the scientists' scientific activity, where argumentative persuasion strategies are developed, and the interpretative principles favored by the authors and legitimized by the peers are put forward.

\section{Heuristic Perspectives on the Future}

It is possible to distinguish different enunciation regimes and visions of the future, through which the diverse actors try to overcome uncertainties and indeterminacies regarding the future.

These different regimes have in common the fact that they link the great argumentative figures and common experiences, marked by the tension between a reticent discourse about the possibility of thinking about the future, based on what is known about the past and the current course of action, and the need to develop minimal control over the future - the immediate future, 
Time Modulation

\begin{tabular}{ll}
\hline Urgency & $\begin{array}{l}\text { Lacking time. It is subtracted by the } \\
\text { force of the event }\end{array}$ \\
\hline Wait & Suspended time
\end{tabular}

\begin{tabular}{ll}
\hline Anticipation & Accelerated time \\
\hline Forecast & Calculated and linearized time \\
\hline Foresight & $\begin{array}{l}\text { Extended, nonlinear time, open to a } \\
\text { plurality of temporalities }\end{array}$ \\
\hline Promise & $\begin{array}{l}\text { Logic of waiting and postponement for } \\
\text { the future }\end{array}$ \\
\hline
\end{tabular}

Prophecy Eschatological time, creating an invisible bridge between the immediate and eternity

\section{Action Logic}

Race against the clock to save a situation (or conquer a position); presentism dominates and the time required for action exceeds the time provided by the situation.

The continuous shift in the waiting horizon; the experience of duration requires patience; absence of a univocal vision of what may happen.

Action on the ongoing process; it draws on outstanding precedent situations; it overcomes the alternative of urgency and waiting for preparedness; acting upstream, in advance, without waiting, before it is too late.

Device, model, calculation space, projection, extrapolation and planning.

Scenario-building of the futures, openness to possibilities, varying degrees of uncertainty.

Project carried out by an actor who seeks to convince others; credibility depends on the announced deadline and the articulation of "already being" and "not being yet". Keep promises, promise, commit to; announce.

Vision supported by an enunciator transformed into a herald; asymmetry between the visionary and their goals clouded by the present and the habit. Fatality: inevitably, unavoidably, there is no way around it.

Source: Adapted from Chateauraynaud (9).

within the reach of actions that may depend on long-term visions of the future, and vice versa (9). Table 1 presents the enunciation regimes and visions of the future advocated by Chateauraynaud (9).

Anticipation is considered as a notion that translates the action that includes the dimensions of forecasting the future, assessing a plausible future situation and an action. Anticipation encompasses two complementary logics: pre-activity and pro-activity. The first activity aims to anticipate foreseeable changes to better prepare for them and take advantage of them. The "futures studies", "forecasting", and "scenario planning" approaches are inherent in it. The second, more proactive, seeks to bring about the changes desired by the action (innovation, for example, to conquer markets). If, on the one hand, this proactive vision is familiar to those who advocate "strategic planning", on the other hand, it is often regarded with suspicion by those who advocate the market economy, who distrust the heralds of economic and social planning.

The issues of sustainable (or durable) development, future responsibility towards the planet and future generations, or regulation and better governance of financial systems are rooted in this proactive attitude towards the future (10). In summary, anticipation, on the one hand, focuses on the short-term, favoring foresights based on the main trends, and, on the other hand, seeks to identify breaks and discontinuities in known models.

A forecast is a probabilistic estimate of the future based on past or present information. A forecast would be a probabilistic statement, an assessment with a certain degree of confidence of the evolution of a trend for a given horizon, a numerical assessment based on data from the past and on some assumptions (11, 12). Forecasting would be a need, a choice and an attitude: as a need, forecasting emerges in a complex and uncertain context; as a choice, forecasting can be seen as the intention to identify the possible consequences of current actions and indicate, among several possibilities, the most appropriate actions to at- tain certain goals; as an attitude, forecasting can be seen as an intention of action and mediator between thinking and acting, an organized predisposition to respond in a certain way to future situations $(13,14)$.

Prediction, unlike forecasting, refers to a non-probabilistic statement, with an absolute level of confidence about the future, with non-probabilistic being understood as a statement that is intended to be unique, accurate, and not subject to controversy. As Jantsch maintained,

A forecast is a probabilistic statement with a relatively high degree of confidence about the future. A prediction is an apodictic (non-probabilistic) statement with absolute confidence, and about the future. An anticipation is a logically constructed model and that concerns a possible future, with a degree of confidence not yet defined $(15$, p.16).

Prediction is based on deterministic theoretical assumptions and produces statements that seek to be as precise as possible about what will happen in the future (16). It emphasizes a discourse about a future condition, based on the reasoning that the anticipator does not make explicit. Thus, in the discourses, actions and/or recommendations of those who make a prediction, a high level of confidence is implicit (17). Prediction, in a strict sense, favors a way of explaining interrelated variables when one of them is time and is projected onto a future date. The simplest way to predict a phenomenon would be to observe whether its occurrence in the past was subject to regularities and whether trends were established (18). It expresses the confidence that the explanatory series would occur over time, over a period of time to be assessed (18). This confidence would be based on the belief that there would be an order, regularity in the observed phenomena. However, there are two major drawbacks to developing rigorous predictive studies in social sciences: the multiplicity of factors that can shape a given phenomenon; and the impossibility of experimenting (18) 
Forecasting seeks to identify the probability of future events with a relatively high level of confidence. By ascribing the probability of occurrences of a given event, the pretension of total accuracy and absolute certainty - a feature underlying prediction - is nuanced, and the centrality of the quality of the statements and the interpretations made is emphasized (19). A forecast is different, in its formulation, from a prediction. Forecast works within a network of definable causal relationships between events, that is, always relationships of interacting variables that result in a particular state of the future. Underlying forecast is an "if, then" type of reasoning, which seeks to guide action, rather than intending to state law. However, forecasts are valid according to the premises underlying them; if the assumptions are weak, the conclusions will also be weak. Therefore, in the studies of the future, sociology and the social sciences could favor the analytical potential of forecasts, rather than claiming to make predictions (19).

Projections analyze trends and cycles that come from the past, happen in the present, and are expected to shape the future in a linear way. The basic feature of a projection is that it takes on the continuity of a historical or statistical pattern, which reproduces the causality of the past (19). For example, in economics and demography, it is possible to establish historical data series and extrapolate trends. If, on the one hand, forecasting is characterized by building a future in the image of the past, whereas foresight is oriented towards one or several futures, on the other hand, forecasting presents static relationships, fixed structures, whereas foresight presents dynamic relationships, evolving structures, focusing on decision-making and building the desired future (20). The projection is a reference standard for the decision-maker $(19,21)$.

Unlike projection, foresight conceives that this historical reference pattern can change in the present. Foresight - equivalent to the French term "prospective" - designates a discipline that is dedicated to anticipation to clarify the present action in the light of possible and desirable futures (22). Although the term "foresight" has an underlying idea of participatory debate, it does not favor the idea of project and pro-activity.

Foresight may be considered an analysis procedure that starts from the study of uncertainties, considering the possible disruptions and risks in an attempt to, logically, highlight different images of the future (possible futures), in a process that materializes the reduction of the complexity of the system in question. Therefore, forecasting has models as its main simulation tool, whereas foresight has scenarios as its main simulation tool $(23,24)$.

The main purpose of foresight analysis is to anticipate in order to act (23). According to Alvarenga and Carvalho (25), the great interest of this type of studies lies in the possibility of exploring the future in a participatory, organized, structured, consistent, plausible and useful way. Among other benefits over other ways of studying the future, foresight analysis enhances communication and coordination between actors and stakeholders, the focus on the long-term (a requirement), the construction of a shared vision that facilitates the focus of actors, managing uncertainties, boosting more inclusive exercises and strengthening networks and interfaces (social capital), the contribution to the definition of priorities (in a context of significant restrictions in terms of resources and growing international competition) and the creation of commitments (of participation and implementation) (25).

Regarding the distinction between propheticism and forecasting, it is possible to name several features. Propheticism takes as its starting point a critical point of view about current society and, often also about the past. Scientific forecasting, on the other hand, is neither critical nor inspired by certain values. Starting from a vision of the past and the present, it tries to discern the possible paths to follow, according to the greater or lesser influence exerted by different factors, conditions and agents. The forecast is essentially based on an analysis of the specific weight of different variables and their possible consequences. Propheticism has a voluntary nature, aims to inspire an orientation and seeks to influence the course of history. While announcing the future, the prophet wants to inspire the forces that will make it as it should be. Forecasting, per se, is not animated by such intentions. Forecasting implements the range of what is possible and probable, accounting for the different variables in action. Prophecy is often characterized by a certain degree of security. It announces with certainty the ineluctable meaning of history. The prophet foretells the future more accurately when he/she claims, simultaneously, that it will be in this specific way and in no other way. This is why a mixture of determinism and pro-activeness is often observed in almost all forms of prophecy. Forecasting, on the contrary, is essentially relativistic and probabilistic. Propheticism can generally be qualified as optimistic or pessimistic, depending on the nature of its omens. This is not the case with forecasting. A forecast can be said to be either encouraging or gloomy, but not optimistic or pessimistic, as is the case with prophecy (26).

Propheticism reveals a meta-scientific order of thought that follows paths that are not inspired by the canons of scientific research, but that respond to a reflection whose principle is to adhere to certain ideas, values and beliefs. The prophet may adhere to certain religious values. In the latter case, his/her reflections and predictions emanate from a divine revelation. However, modern propheticism is not normally religious but rather the result of a philosophical or moral reflection on the essential nature and destiny of the individual and society (26).

\section{Sociology, Social Change and Future}

The founders of sociology were able to conceive of a social order that was not detected by reducing all change to something immutable, but rather, which showed itself as an immanent order of change (27). These authors were focused on the question of a new and better order that they hoped and believed would emerge in the not-too-distant future. They considered it an axiom that the future condition of humanity should be better than that of their time, shaping a type of social religion, expression of the belief that society evolved and progressed smoothly (27). However, the direction of this scientific progress was highly variable, according to the diversity of political and social ideals held by the various founders. In the process of institutionalizing sociology, sociologists analyzed contemporary society in the light of history, but also in relation to the future, often prophesying the developments and structure of future society.

Underlying the idea of progress is a notion of irreversible 
time, which flows in a linear way and provides continuity between the past, the present and the future. Progress entails the positively assessed difference between the past and the present progress achieved - or between the present and the future progress expected (28). However, scientific sociology deems that progress is, first and foremost, a moral concept, and it may possibly found one of the points of view from which the discourse proceeds; whether it is legitimate to speak of the movement of history or social transformation, ascribing them a qualitative direction is beyond the competence of scientific procedure (29). The criticism of the notion of progress inherent in the organic-systemic models of society and the dichotomy between social statics and social dynamics emphasizes the dynamic and permeable qualities of social reality and the dereification of social reality (28).

The conceptual emphasis on the process would make it possible to overcome static-dynamic, structure-action, diachronic-synchronous dichotomies; the process may be seen as the connection between action and structure. This process is open, sequential and cumulative; at each stage, actions are undertaken based on certain conditions and possibilities produced in the past, which, in turn, transform the circumstances for the future.

Hence, society can be understood as a process historically built by individuals who are historically built by society $(6,28)$. As Elias points out, a configuration had to arise from a given previous configuration, or even from a certain type of sequential series of configurations but the author does not claim that the previous configurations had, necessarily, to become those that follow (27).

It is acknowledged that the ability to make forecasts or predictions is difficult to achieve in sociology (30-33). Elias argued that "A model that shows how and when a past configuration of relatively centralized and undifferentiated social units evolves towards a more centralized and complex configuration the suspicion easily arouses that, in his/her research, the researcher projected into the past his/her present and future goals and desires" $(27$, p.173). It should be noted, on the one hand, that a configuration flow does not inevitably have to produce a given more complex configuration, and, on the other hand, that certain forecasts can be made about the evolution of a given configuration (27). This difficulty in making forecasts stems from the assumptions that a scientific explanation is understood as unilinear and causal and from the centrality of the idea of a "first cause" (27).

In contrast, in the positivist paradigm, the success of the forecast should be adopted as a fundamental epistemological, axiological and methodological criterion of science in general. As such, its scientificity is measured by the degree of coherence between reality and forecasting: the higher this coherence, the more solid will be the scientific statute of the discipline. According to this perspective, a given science is capable of anticipating future scenarios and results with a high degree of precision and with progressively reduced margins of error $(34,35)$. However, in general, forecasts do not have only an eminently descriptive purpose, i.e., they are not only a scientifically supported anticipation of a future scenario. These forecasts also have a performative meaning, insofar that they are conceived as instruments that can intervene in the formation of social reality and, consequently, in the type of response given by social agents (35).

Social reflexivity $(4,35-38)$ is a very striking feature in sociology and social sciences because, in the words of Haro (35) it, "[...] is a concept that draws attention to the influence of forecasts on society and, simultaneously, of society on forecasts" ( $p$. 150). Forecasts in social sciences have a reflexive nature, as Merton (39) explained, in addition to highlighting the unexpected or involuntary effects of social action. The author mentions the self-fulfilling prophecies as false definitions of situations that generate new behaviors, making the originally false conceptions true. Self-denying prophecies are viewed as a certain definition of the situation that gives rise to a new behavior that falsifies the originally true conception (39). The requirements for these types of prophecies to be produced are: that it is a social prophecy, that it is known by the relevant actors and that as a result, they shift their behavior (40).

Uncertainty is relevant in any consideration of future scenarios, inasmuch that, being elements that can evolve in the future in different ways, they allow the exploration of alternative possible futures (25). The situation of uncertainty cannot be assessed in terms of rational calculation (41). One can speak of "severe" uncertainties - marked by ignorance (uncertainty is present but not acknowledged) and indeterminacy (in which it is acknowledged that scientific assessments are the result of a given definition of the problem and that this is influenced by social, political and scientific choices) - and of epistemic uncertainties (resulting from incomplete knowledge, and which can be solved with further research) (41-43). A risk-based conception can lead to a process of risk mitigation, negotiation and acceptance, whereas an approach that emphasizes uncertainty (in the sense of ignorance and indeterminacy) can promote a prudential orientation, as well as the refusal of certain decisions and actions (43).

There may be only one accomplished future, but different anticipated futures, that is, "alternative futures" may be enunciated. Among the alternative futures, the "potential future" is related to events that even imagination does not cover; the "possible future" can be anticipated with imagination beyond current knowledge; the "plausible future" can be accessible with current knowledge; the "probable future" is estimated with current trends; and the "preferable future" is the one that, among the possible, plausible or probable futures, is subjective $(44, \mathrm{p} .1$, 45).

However, as Javeau (29) argues, scientific sociology does not support the idea of predictability of the social future: it can favor a foresight approach and establish probabilistic scenarios, formulating several successive hypotheses. Some of these hypotheses may be more plausible than others (for example, in the field of demographic evolutions) but the forecast cannot go beyond the level of more or less well-argued conjectures, distrusting any prophetic temptation. Sociology is systematically tempted by a utopia: "[...] to find the key to social change and, with it, reduce the uncertainty of the future" (46, p.19). Obviously, in an attempt to reduce uncertainty, the sociologist cannot make prophecy or futurology, nor dwell on prediction using observation and explanation (47). He/she can indeed look at the 


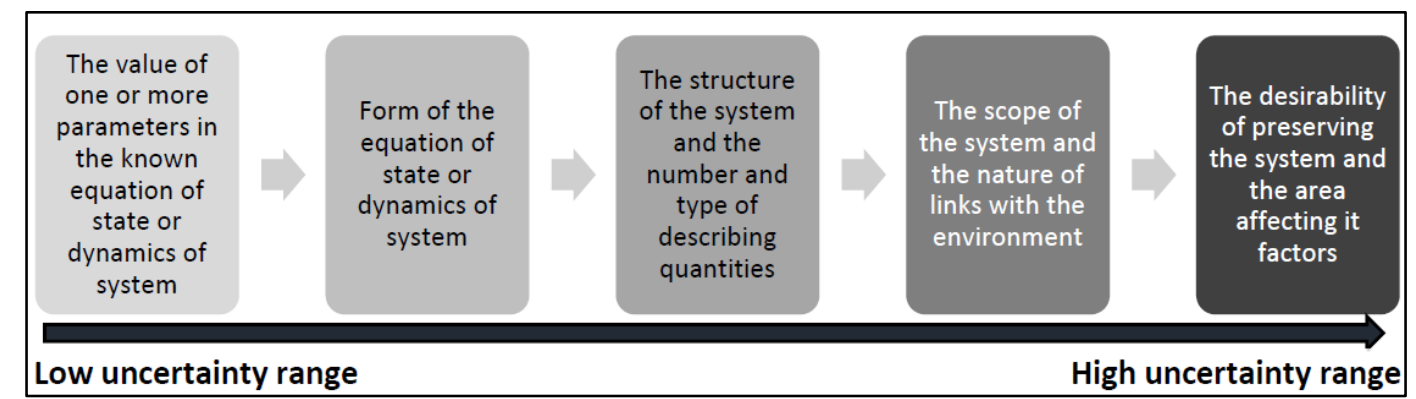

Figure 1. Level of the Scope and Significance of Uncertainty in the Context of the System. Source: Magruk (51, p.48).

future prospectively and, as such, benefit from foresight methods and techniques.

This foresight reflection would encompass a critical understanding of the present, the anticipation of change and the building of scenarios. The critical understanding of the present would favor a systemic analysis of the phenomenon under study, emphasizing three levels of analysis: apprehension, which consists in the delimitation of the system; understanding, which aims at knowing the structure of the system; explanation, which seeks to understand how the system will be shaped in the future (48). The anticipation of change would aim to determine the problems of the future, to guide it in the most desirable direction. Thus, it would be important to identify heavy trends, emerging trends and future-bearing facts. A heavy trend is a stable trend where it is relatively easy to predict the future (48). The emerging trend is not observable as it does not exist in totality; it may arise if a set of phenomena continues to occur, but it may never occur. Future-bearing facts are a sign of change only perceptible in the present, but they may become a heavy trend, hence the high relevance of intuition in foresight reflection (48). Scenario building is a process of the shift of strategic paradigm. Although there are continuity scenarios that do not call the existing paradigm into question, there are break scenarios that entail changes in the organizational structure and, obviously, consequences in terms of established powers. In a foresight approach, through a process of learning and negotiating the construction of alternatives and, in particular, scenarios of continuity or break, as well as the involvement and mobilization of different actors in this dynamic, it is possible to define not only the strategic options but also how to intervene and guide this process of change (48).

Authors who advocate a foresight perspective do not believe that the future is only the result of an extrapolation that follows the logical continuity of the pattern. On the contrary, they exalt the issue of social change, pointing out the permanent transformation that has taken place in established trends or apparently unmodifiable historical patterns (19).

Foresight as a methodology can improve sociological thinking aimed at analyzing megatrends, favoring an interdisciplinary perspective that emphasizes the search for alternative futures, encouraging active participation in public debate and decision-making. Therefore, the role of foresight would not be so much to predict but to help, informing decision-making on relevant issues. The foresight of studies of the future could be mobilized in different contexts of sociological research, allowing the use of processes and methods of strategic foresight for the analysis of companies and territories (organization of seminars on foresight; elaboration of the company/organization diagnosis; identification of the key variables; analysis of the actors game; analysis of the field of the possible and reduction of uncertainty; assessment of strategic options) (10), enabling to know the key variables of a system where the involvement/participation of actors in the process of change is pivotal for collective action, for the construction of a "desired future" (49).

However, one of the main limits of foresight analysis is embodied in the "announcement effect": the idea that the diffusion of an evolution that is awaited with expectation may cause reactions that come to influence this evolution, due to insufficient information, inaccuracy of the data (statistical or otherwise), instability of models, interpretation errors and epistemological obstacles $(12,50)$.

In Magruk's approach to this issue, the degree of uncertainty associated with the foresight approach is related to the objective essence of phenomena randomness, as well as to the subjectivity inherent in human beings (51). The future-oriented perception of human activities is characterized by an incomplete specificity of phenomena, by their volatile nature and by their rupture. An individual is unable to determine with complete certainty the course that a given phenomenon will take in the future.

In the context of systems analysis, Magruk offered a reading of the changes that take place in these systems along a continuum (Figure 1).

The wider the horizons and the analysis, the more uncertainty there is. This is due to the complexity of the systems themselves, in terms of their features, structures and behaviors. This complexity extends beyond what is objectively observable and verifiable through existing knowledge (51).

\section{Conclusion}

Sociology has something relatively specific vis-a-vis other disciplinary-professional fields: an acute sociological self-aware- 
ness, a permanent sociological self-reflexivity on sociology as a social practice and system of representations, a stage for conflicts of interest and power games, on the practice of sociology as a scientific and professional activity that is socially conditioned, socially produced and always with social consequences (36).

Sociology analyses trend social dynamics and social interconnections from their relationship with institutional realities. The functions of this hermeneutic science are mainly two: (i) a negative function, of unmasking reality, that is, it tends to have an anti-formalist reading of social dynamics, which is outlined as an intrinsic critical capacity of this discipline, which is why it has always been deemed dangerous by totalitarian and undemocratic regimes; and (ii) a positive function, as an analysis of the social implications of actions and social structures on social experience, that is, it observes the gap between the expectations of an action (political, economic, social) and the real consequences of the experience through of the interconnections between phenomena, observing their degree of conditioning (52).

In turn, Chattoe-Brown argues that "No theory of social action can credibly be applied generically" $(53$, p. 2$)$. Furthermore, interdisciplinarity must be mobilized by fostering interdisciplinary collaboration, whenever necessary, to substantiate and build trust in our knowledge of the past, present and expectations about an increasingly digitalized future (54-58).

An attitude of promotion of interdisciplinarity between sociology, history and other social sciences of questioning science and mobilizing epistemological and methodological principles that guide social research can be a central strategy in overcoming the prophetic common sense with which the social sciences struggle, and enhance its heuristic capabilities: relativization of human phenomena; valuation of socio-historical contexts and coordinates of time and place; relationship of social phenomena and insertion of these phenomena in systems of reciprocal relationships, empirically verifiable; and reflective questioning and questioning of all accrued knowledge, including common sense, ideologies and science itself $(59,60)$.

Sociology, and all social sciences as well, contribute to changing reality in a more or less intentional way. For Reinprecht et al.,

Sociology, especially as an empirical science, is more than just an intellectual relation as it always unfolds in concrete physical contexts and places, relevant for the production of knowledge, for the development and application of research methods, for the circulation and transmission of knowledge, and for the realization of social concepts through interventions in society $(61, p .16)$.

The results of the analysis put forward in this conceptual paper allow verifying and concluding that (i) sociology and social sciences, given the features of their object of study - facts and social situations - deal with trends; (ii) personal ideology may influence the attempt to anticipate the future; and (iii) the dissemination of information from social sciences has the potential to change reality and, consequently, call into question their capacity for the social forecast. These conclusions do not detract from the merits of social sciences, entailing the need for awareness of these features in the social scientific approach.

\section{Acknowledgement}

The authors would like to thank to the Editor and Reviewers for their comments and suggestions.

\section{References}

1. Horkheimer M. Sur le problème de la prédiction dans les sciences sociales [On the problem of prediction in the social sciences]. Variations [Online], 1933; 23. DOI: https://doi.org/10.4000/variations.1543

2. Comte A. Cours de philosophie positive. Introduction et commentaires par Florence Khodoss [Positive philosophy course. Introduction and comments by Florence Khodoss]. La Gaya Scienza. 2012.

3. Popper K. The poverty of historicism. New York: Harper \& Row. 1964.

4. Serpa S, Ferreira CM. Sociology as scientific knowledge. J Educ Soc Res 2019; 9(3):178. DOI: https://doi.org/10.2478/jesr-2019-0035

5. Silva AS, Pinto JM. Uma visão global sobre as ciências sociais [A global view on social sciences]. In

Silva AS, \& Pinto JM (Orgs.), Metodologia das ciências sociais [Methodology of social sciences] 1986; (pp. 9-27). Porto: Edições Afrontamento.

6. Abrams P. Historical sociology. Ithaca: Cornell University Press. 1982.

7. Schulz M. Debatendo futuros: Tendências globais, visões alternativas e discurso público [Debating futures: Global trends, alternative views and public discourse]. Sociol Antropol 2014; 4(1):71-95. DOI: https://doi.org/10.1590/2238-38752014v414

8. Dator J. What futures studies are, and are not. Hawaii: University of Hawaii, Hawaii Research Center for Futures Studies. 2007.

9. Chateauraynaud F. Des prises sur le futur. Regard analytique sur l'activité visionnaire [Holds on the future. Analytical look at visionary activity]. 2012. In D. 
Bourg, P.-B. Joly, \& A. Kaufmann (Dirs.), Retour sur la société du risque - Actes du colloque de Cerisy [A look back at the risk society - Proceedings of the Cerisy conference]. Cerisy-la-Salle, France, September 3-10, 2011.

https://www.gspr-ehess.com/documents/articles/FCPrises-sur-le-Futur-janv2012.pdf

10. Godet M, Durance P, Dias J. A prospectiva estratégica para as empresas e os territórios [Strategic foresight for companies and territories]. Paris: LIPSOR. 2008.

http://www.laprospective.fr/dyn/francais/actualites/TO POSPortugaisV190510.pdf

11. Godet M. Crise de la prévision, essor de la prospective [Forecast crisis, foresight boom]. Paris: PUF. 1977.

12. Godet M. Manual de prospectiva estratégica. Da antecipação à acção [Strategic foresight handbook. From anticipation to action]. Lisboa: Publicações D. Quixote. 1993.

13. Masini E. La previsión humana y social. Estudios sobre los futuros [The human and social foresight. Studies on futures]. Mexico City: Centro de Estudios Prospectivos de la Fundación Javier Barros Sierra/FCE. 1993.

14. Masini E, Medina Vasquez J. Scenarios as seen from a human and social perspective. Technol Forecast Soc Change 2000; 65(1):49-66. DOI: https://doi.org/10.1016/S0040-1625(99)00127-4

15. Jantsch E. La prévision technologique: Cadre, techniques et organization [Technological forecasting: Framework, techniques and organization]. Paris: OCDE. 1967.

16. Miklos T, Tello M. Planeación prospectiva. Una estratégia para el diseño del futuro [Foresight planning. A strategy for the design of the future]. Limusa: Centro de Estudios Prospectivos de la Fundación Javier Barros Sierra. 1995.

17. Rattner H. Considerações sobre tendências da futurologia contemporânea [Thoughts on trends in contemporary futurology]. Rev Administ Empres 1973; 13(3):89-103.

18. Cobos A. Hacia la sociología de los futuros [Towards the sociology of futures]. Naucalpan de Juárez, Mexico: Pearson Educación de México. 2011.

19. Ribas J. Planejamento educacional baseado em cenários prospectivos na educação à distância [Educational planning based on foresight scenarios in distance education]. Doctoral dissertation. Florianópolis: Universidade Federal de Santa Catarina. 2013.

20. Schenatto FJA, Polacinskill E, Abreu AF, Abreu PF. Análise crítica dos estudos do futuro: Uma abordagem a partir do resgate histórico e conceitual do tema [Critical analysis of studies of the future: An approach based on the historical and conceptual rescue of the theme]. Gestão Produção 2011; 18(4):739-754. DOI: https://doi.org/10.1590/S0104-530X2011000400005

21. Vasquéz JM, Órtegon E. Manual de prospectiva y decisión estratégica: Bases teóricas e instrumentos para América Latina y el Caribe [Handbook of fore- sight and strategic decision: Theoretical bases and instruments for Latin America and the Caribbean]. Mexico City: Instituto Latinoamericano y del Caribe de Planificación Económica y Social (ILPES). Naciones Unidas, CEPAL. 2006.

22. Martin B. Technology foresight: Capturing the benefits from science-related technologies. Res Eval 1996; 6(2):158-168. DOI: https://doi.org/10.1093/rev/6.2.158

23. Saragoça J. Diagnóstico e prospetiva social [Diagnosis and social foresight]. Évora: Universidade de Évora. 2012

24. Jouvenel H. La démarche prospective. Un bref guide méthodologique [The foresight approach. A brief methodological guide]. Futuribles, 1993; 179:51-71 (updated in 2002). Paris: Futuribles International.

25. Alvarenga A, Carvalho PS. Escola francesa de prospectiva no contexto dos futures studies - Da "Comissão do Ano 2000" às ferramentas de Michel Godet [French School of foresight in the context of future studies - From the "Year 2000 Committee" to Michel Godet's tools]. Lisboa: Ministry of Environment, Spatial Planning and Regional Development Department of Foresight and Planning. 2007.

26. Rocher G. Introducción a la sociología general [Introduction to general sociology], 12th ed. Barcelona: Herder. 1996.

27. Elias N. Introdução à sociologia [Introduction to sociology]. Lisboa: Édições 70. 1980.

28. Sztompka P. Sociología del cambio social [Sociology of social change]. Madrid: Alianza Editorial. 1995.

29. Javeau C. Lições de sociologia [Lessons of sociology]. Oeiras: Celta Editora. 1998.

30. Bootz JP, Durance P, Monti R. Foresight and knowledge management. New developments in theory and practice. Technol Forecast Soc Change 2019; 140:80-83. DOI: https://doi.org/10.1016/j.techfore.2018.12.017

31. Cazes B. Prospetiva [Foresight]. In R. Boudon, P. Besnard, M. Cherkaoui, Lécuyer BP (Dirs.), Dicionário de sociologia [Dictionary of sociology] (p. 199). Lisboa: Publicações Dom Quixote. 1990.

32. Rocher G. Sociologia geral. A organização social [General sociology. The social organisation]. Lisboa: Editorial Presença. 1989.

33. Šubrt J. Ulrich Beck: The metamorphosis of the world. Histor Sociol 2018; 1:150-153. DOI: https://doi.org/10.14712/23363525.2018.44

34. Lucas R. Macroeconomic priorities. Am Econ Rev 2003; 93(1):1-14. DOI: https://doi.org/10.1257/000282803321455133

35. Haro FA. A insustentável sustentabilidade das previsões económicas: Reflexividade, etnoeconomia e neoliberalismo [The unbearable sustainability of economic predictions: Reflexivity, ethno-economics and neoliberalism]. Sociologia, Revista da Faculdade de Letras da Universidade do Porto, 2015; XXX:145-164.

36. Costa AF. Sociologia [Sociology]. Lisboa: Difusão Cultural. 1992. 
37. Ferreira C., Serpa S. Challenges in the teaching of sociology in higher education. Contributions to a discussion. Societies 2017; 7(4):30. DOI: https://doi.org/10.3390/soc7040030

38. Serpa S, Ferreira CM. Sociological problem and social problem: Contributions to a discussion. Sociol Anthropol 2018; 6(11):840-844. DOI: https://doi.org/10.13189/sa.2018.061104

39. Merton R. Social theory and social structure. New York: Free Press. 1968.

40. Espinosa E, García J, Albero C. La sociología del conocimiento y de la ciência [Sociology of knowledge and science]. Madrid: Alianza Editorial. 1994.

41. Martins H. Risco, incerteza e escatologia: reflexões sobre o experimentum mundi tecnológico em curso (II) [Risk, uncertainty and eschatology: Reflections on the ongoing technological experimentum mundi (II)]. Episteme, 2, June-July, 1998; pp. 41-75.

42. Wynne B. Uncertainty and environmental learning: Reconceiving science and policy in the preventive paradigm. Glob Environ Change: Hum Policy Dimens 1992; 2(2):111-127.

http://tbauler.pbworks.com/w/file/fetch/48548191/Wy nne uncertainty\%20and\%20enviornmental\%20learni ng.pdf

43. Jerónimo H. A peritagem científica perante o risco e as incertezas [Scientific expertise in the face of risk and uncertainties]. Análise Social 2006; XLI(181):1143-1165.

44. Çifci $H$, Yuksel N. Foresight 6.0: The new generation of technology foresight. 2018 IEEE International Conference on Engineering, Technology and Innovation (ICE/ITMC) (pp. 1-5). Stuttgart, Germany, June 17-20, 2018. DOI: http://doi.org/10.1109/ICE.2018.8436350

45. Voros J. A generalised 'layered methodology' framework. Foresight 2005; 7(2):28-40.

46. Boudon R. Effets pervers et ordre social [Perverse effects and social order]. Paris: PUF. 1977.

47. Decouflé A. Traité élémentaire de prevision et de prospective [Elementary treatise on forecast and foresight]. Paris: Presses Universitaires de France. 1978.

48. Perestrelo M. Prospectiva e mudança social [Foresight and social change]. In J. Saragoça, C. A. Silva, \& J. Fialho (Eds.), Prospetiva estratégica: Teoria, métodos e casos reais [Strategic foresight: Theory, methods and real cases] (pp. 111-126). Lisboa: Edições Sílabo. 2017.

49. Soares $P$, Chainho $C$, Balão $A$. Limites da prospetiva e potencialidade dos "estudos do futuro" em sociologia [Limits of foresight and potential of "studies of the future" in sociology]. In Atas do IX Congresso Português de Sociologia [Proceedings of the IX Portuguese Congress of Sociology]. Faro: Portuguese Association of Sociology. 2016.
50. Saragoça J, Silva C, Fialho J. Antecipação de cenários de mudança com metodologia prospectiva: Teoria e estudos empíricos [Anticipating change scenarios with foresight methodology: Theory and empirical studies]. In Sociedades en transición: Afrontando los retos del cambio social - Actas del VIII Congreso Andaluz de Sociología [Societies in transition: Facing the challenges of social change Proceedings of the VIII Andalusian Congress of Sociology]. Almería, November 24-26, 2016.

51. Magruk A. Concept of uncertainty in relation to the foresight research. Eng Manag Prod Serv 2017; $9(1): 46-55$. DOI: https://doi.org/10.1515/emj-2017-0005

52. Riccioni I. Sull'utilità e il danno della conoscenza sociologica [On the usefulness and harm of sociological knowledge]. Culture e Studi del Sociale 2019; 4(1):15-31.

53. Chattoe-Brown E. Does sociology have any choice but to be evolutionary? Front Sociol 2019; 4. DOI: https://doi.org/10.3389/fsoc.2019.00006

54. Ferreira CM, Serpa S. Society 5.0 and social development: Contributions to a discussion. Manag Organ Stud 2018; 5(4):26. DOI: https://doi.org/10.5430/mos.v5n4p26

55. Liyanage JP. Living with digital risk: A critical foresight of human-social-organizational transformations. Fifth International Conference on Information and Automation for Sustainability (pp. 262-267). Colombo, Sri Lanka, December 17-19, 2010. DOI: https://doi.org/10.1109/ICIAFS.2010.5715670

56. Mangone E. Limiti e opportunità delle scienze sociali [Limits and opportunities of the social sciences]. Culture e Studi del Sociale, 2019; 1(4):3-13. http://www.cussoc.unisa.it/volumes/index

57. Serpa S, Ferreira C, Santos A. Fostering interdisciplinarity: Implications for social sciences. Int J Soc Sci Stud 2017; 5(12):44-49. DOI: https://doi.org/10.11114/ijsss.v5i12.2775

58. Kuribayashi M, Hayashi K, Akaike S. A proposal of a new foresight platform considering of sustainable development goals. Eur J Futures Res 2018; 6:4. DOI: https://doi.org/10.1007/s40309-017-0130-8

59. Rowland R. Antropologia, história e diferença [Anthropology, history and difference]. Porto: Edições Afrontamento. 1987.

60. Silva A. A ruptura com o senso comum nas ciências sociais [The break with common sense in social sciences]. In A. Silva, \& J. Pinto (Orgs.), Metodologia das ciências sociais [Methodology os social sciences] 1990; (pp. 29-53). Porto: Edições Afrontamento.

61. Reinprecht $\mathrm{C}$, Walch N, Šubrt J. Mapping the history of sociology: Places, positioning, dominance and marginality in an emerging discipline. Historická Sociologie 2019; 1:11-27. DOI: https://doi.org/10.14712/23363525.2019.2 